\title{
The effectiveness of treffinger's learning model in increasing creativity and mathematics achievement of gifted students
}

\author{
Kana Hidayati 1, a, *, Ni Kadek Swari Nandini 1, b, Mazlini Adnan 2, c \\ ${ }^{1}$ Department of Mathematics Education, Universitas Negeri Yogyakarta \\ Jl. Colombo No 1, Karangmalang, Yogyakarta 55281, Indonesia \\ ${ }^{2}$ Department of Mathematics, Universiti Pendidikan Sultan Idris \\ Upsi, 35900, Tanjong Malim, Perak, Malaysia \\ E-mail: ${ }^{\mathrm{a}}$ kana@ uny.ac.id, ${ }^{\mathrm{b}}$ swarinandini0612@gmail.com, ${ }^{\mathrm{c}}$ mazlini@fsmt.upsi.edu.my \\ * Corresponding Author
}

\begin{tabular}{ll} 
ARTICLE INFO & ABSTRACT \\
\hline $\begin{array}{l}\text { Article history } \\
\text { Received: } 24 \text { Aug. } 2021\end{array}$ & $\begin{array}{l}\text { This study aims to describe the difference in creativity and mathematics } \\
\text { achievement between gifted students who were taught by Treffinger's learning } \\
\text { and those who thought by the expository learning in trigonometry material. This } \\
\text { Accepted: } 29 \text { Nov 2021 } \\
\text { study is a quasi-experiment using a pretest-posttest group design with a } \\
\text { population of all gifted students in class X of a State Senior High School in }\end{array}$ \\
$\begin{array}{l}\text { Keywords } \\
\text { Breativity, gifted, } \\
\text { mathematics achievement, } \\
\text { treffinger }\end{array}$ & $\begin{array}{l}\text { been validated. The data were analyzed descriptively and inferentially with the } \\
\text { paired sample t-test to test the mean difference of the pre-test and post-test data. }\end{array}$ \\
Scan me: & $\begin{array}{l}\text { The results show that the average creativity of students in the experimental class } \\
\text { is significantly higher by 9.46 points than that of the control class. In terms of } \\
\text { mathematics learning achievement, the average gain score in the experimental } \\
\text { class increased significantly by 58.365 points. It can be concluded that } \\
\text { Treffinger's learning is effective in increasing creativity and mathematics }\end{array}$ \\
achievement of gifted students in trigonometry material.
\end{tabular}

This is an open access article under the CC-BY-SA license.

How to Cite: Hidayati, K., Nandini, N. K. S., \& Adnan, M. (2021). The effectiveness of treffinger's learning model in increasing creativity and mathematics achievement of gifted students. Jurnal Riset Pendidikan Matematika, 8(2), 128-139. https://doi.org/10.21831/jrpm.v8i2.43397

\section{INTRODUCTION}

Education is a conscious effort to obtain a quality life. Education that has the aim of helping children develop their potential is the right action in dealing with problems that occur in the future. The development of the 21 st century which is increasingly advanced and modern can help make it easier for individuals to obtain an education. This is what is currently a demand so that each individual can develop their abilities so that the quality of the individual must be met with the quality of education as well. The quality of education includes aspects of intelligence (Maharani, 2018: 506).

Citizens who have the potential for intelligence and special talents are entitled to special education. Someone who has the potential for extraordinary intelligence and special talent belongs to the type of gifted child or special intelligent child. Special intelligent children are unique individuals and have characteristics and needs that are relatively different from normal children in general (Sunardi, 2008: 2). Gifted children are special intelligent children who have an intelligence group called very intelligent (Very Superior/Gifted) with an Intelligence Quotient (IQ) ranging from 125 to 140 (Khumaidi et al., 2019: 22). The characteristics of gifted children are having attention to science, high curiosity, strong imagination, and really like to read (Desiningrum, 2016: 23). 
According to Renzulli in the Three Rings of Renzulli, a child is said to be a special intelligent child (gifted) in this case a child who can realize his achievements well, if he fulfills several conditions, namely the child has a high intelligence capacity or has above average abilities, have high creativity in solving problems and building something new, as well as having high motivation and commitment to tasks (Tiel et al., 2014: 3). In addition to the special things that gifted children have as characteristics, they have, in the empirical life of gifted children also experience problems related to the characteristics they have. The problem experienced by gifted children is that they often experience boredom, lack of enthusiasm, frustration, anger, and feeling less valuable (Idrus, 2013: 117). The problems experienced by gifted children can cause delays in the development of their potential, one of which can inhibit creativity in gifted children (Wandansari, 2011: 32).

One of the means to develop creativity for gifted students in the field of education is through learning mathematics. The process of learning mathematics trains students to think creatively, especially in solving problems. One of the goals of learning mathematics in the curriculum to be achieved is to guide students to have a broader view, have an attitude of appreciating the usefulness of mathematics, a critical, objective, open, innovative, and creative attitude. Teachers who teach mathematics are expected to play a role in developing innovative and creative thinking skills in students. Creativity of student, include fluency, flexibility, originality, and elaboration skill. Increased creativity in students in participating in mathematics learning is expected to have a positive impact on learning achievement obtained. The learning achievement in question can be reflected in mathematical communication skills, reasoning, mathematical creative abilities, and problem-solving abilities (Pomalato, 2006: 23). One of the mathematics learning materials that can be used to identify students' creative thinking skills is trigonometry material, especially on the topic of sine and cosine rules. The use of the sine and cosine rule material can measure the level of student creativity, this is due to the heterogeneous solution. In general, students only use one way to solve math problems, even though there are several different ways to solve problems in a problem (Wulandari \& Afifah, 2019: 60).

One approach that can be used to maximize the mathematics learning process for gifted students is the Treffinger's learning model (Maharani, 2018: 507). Several previous studies have shown the application of the Treffinger's learning model to students for mathematics subjects. Wiladah et al. research evaluated Treffinger's learning model for class XI high school students, while Isnaini et al. research evaluated Treffinger's learning model for seventh-grade junior high school students. However, from several studies that have been carried out, no research discusses the use of the Treffinger's learning model in gifted students. Whereas gifted students are one of the potential targets of the application of the Treffinger's learning model (Isnaini et al., 2016: 42; Wiladah, 2017: 67).

The Treffinger's learning model was first introduced by Donald J. Treffinger in 1980 (Sari \& Putra, 2015: 31). The Treffinger's learning model is a learning model that applies creative learning processes by using divergent thinking processes (thinking processes that go in various directions and can obtain many alternative solutions) and convergent thinking processes (thinking processes by looking for the most appropriate solution) (Darminto, 2013: 103). The Treffinger learning model can provide flexibility for students to find alternative solutions to a problem independently and students are given the freedom to express their ideas, and students are given the freedom to formulate and design ways to solve a problem. So from that, it will help students in bringing out their creative thinking and through creativity will be able to explore the potential of students in being creative, finding ideas, and solving problems (Akbar et al., 2015: 38). The Treffinger's learning model has advantages: (1) The Treffinger's learning model is based on the assumption that creativity is a process and an outcome in learning; (2) This model can be applied to all students from various backgrounds and levels of knowledge; (3) This model has a focus on aspects of cognitive and affective dimensions in its development process; (4) There is gradual involvement in the ability to think convergently and divergently in the process of solving a problem; (5) Has systematic development stages with various ways and methods that can be carried out in flexible stages (Sari \& Putra, 2015: 32). The steps of the Treffinger's learning model consist of basic tools, practice with the process, and working with real problems (Nisa, 2011: 40).

The researchers survey in one of the formal schools that provide education in Denpasar, Bali, Indonesia, ie. a state senior high school. Based on the preliminary survey that has been carried out, it was found that the school has gifted students as students who take part in the teaching and learning process at this school. The process of learning mathematics at this school generally uses expository learning model. Based on the description above, the authors are interested in conducting research on the 
effectiveness of the Treffinger's learning model in increasing creativity and mathematics achievement of gifted students. This study aims to describe the effectiveness of Treffinger's learning model in increasing creativity and mathematics achievement of gifted students on trigonometry material on the topic of the sine and cosine rules.

\section{METHOD}

\section{Research design}

This research is an experimental study with a quasi-experimental design with a pretest-posttest group design. In both groups, both the experimental group and the control group were given a pre-test which aims to measure the condition of the group before being given treatment. Then, treatment was given to the experimental group in the form of learning mathematics using the Treffinger's learning model on trigonometry material on the topic of the sine and cosine rules, while the control group was given learning using expository learning models. In the end, a post-test was conducted to measure the condition of the experimental group and the control group after being given treatment.

\section{Research sample}

The research data collection was carried out at a state senior high school in Bali, Indonesia. The target population in this study were all gifted students at the school. The affordable population in this study were all gifted students in class X at the school in the 2020/2021 academic year. The research sample came from gifted students with IQ in the range of 125-140 who were in class X in the science department of the school. The sample criteria in this study were samples that met the inclusion criteria and did not meet the exclusion criteria.

The inclusion criteria in this study were having an IQ ranging from 125 to 140 and having been declared competent from the results of psychological tests carried out at the school at the beginning of new student admissions. The exclusion criteria in this study were students who quit or withdrew at the time of the study. Based on the calculation of the sample size, the minimum number of samples in this study was 45 students in the experimental class and the control class. Sampling was done by purposive cluster random sampling technique, namely by taking a population of gifted students who met the inclusion criteria and did not meet the exclusion criteria, then randomization was carried out to get a sample of gifted students who would be included in this study until the minimum sample was met.

\section{Research variables}

The variables in this study include the IQ scores of gifted students, student creativity, student achievement, and Treffinger's learning model. The IQ score of gifted students is an IQ score that ranges from 125 to 140 with the measuring instrument is school assessment, the measurement results are Yes and No and the scale is nominal. Creativity (as the dependent variable) is the ability to produce something new or the ability to provide new ideas as a solution to problem-solving, with the measuring instrument is a creativity questionnaire, the measurement results are very low, low, medium, high, and very high, and the scale is ordinal. Mathematics achievement (as the dependent variable) is the level of student mastery of mathematics subject matter by looking at the results of student learning tests expressed in the form of scores, with the measuring tools being pre-test and post-test, the results of which are pre-test and post-test scores. Test and the scale is an interval. The Treffinger's learning model (as an independent variable) is a learning model that applies the learning process creatively by using divergent thinking processes (thinking processes by looking for many alternative solutions) and convergent thinking processes (thinking processes by looking for the most appropriate solution). the measurement results are getting the Treffinger's learning model and not getting the Treffinger's learning model and the scale is nominal.

\section{Research instruments}

The instruments used in this study were observation sheets, written tests, and students' creativity instruments. The observation sheet consists of an observation sheet on the implementation of mathematics learning using the Treffinger's learning model and the expository learning model which contains about whether or not each aspect of learning has been achieved using the Treffinger and expository learning models. The written test consists of pre-test and post-test. This written test is in the 
form of a description of 3 questions that are arranged to measure student achievement in learning mathematics. In this study, the student's creativity instrument was in the form of a creativity questionnaire which was distributed online to students in the form of a google form and then filled out by students. The creativity questionnaire contains 32 statements, namely with 16 positive statements and 16 negative statements with answer choices of Very Appropriate (SS), Appropriate (S), Not Appropriate (TS), and Very Incompatible (STS).

To obtain evidence of instrument validity, content validity was used. The procedure for obtaining content validity is to compare the content with the test specifications that describe the domain of the learning outcomes being measured. After the test instrument was prepared based on theory, then to obtain evidence of content validity, it was carried out using expert agreement. In this study, the instrument was validated by lecturer from department of mathematics education Universitas Negeri Yogyakarta and mathematics teacher from the school where the study was conduct. After obtaining validation from experts, then the instrument was tested. The instrument trial was carried out to obtain data on the estimated reliability coefficient of the instrument which aims to determine whether the instrument used can measure something to be measured consistently from time to time.

\section{Data analysis}

The research data were processed using the SPSS statistics for windows version 20.0. The data analysis used in this study was in the form of descriptive and inferential analysis. Descriptive analysis is used to describe the characteristics of the independent variable and the dependent variable. The entire data in the problem will be presented in the form of a frequency distribution table. The variables analyzed were demographic data, creativity scores, and learning achievement of gifted students at a senior high school in Bali, Indonesia regarding the topic of trigonometry on the topic of sine and cosine rules.

Meanwhile, inferential analysis is used to determine the effectiveness of using the Treffinger's learning model as an independent variable on the dependent variable in this study, namely creativity and mathematics achievement. Before the analysis, the data normality test was carried out using the Kolmogorov-Smirnov test first. If the data is normally distributed, to determine the effectiveness of using the Treffinger's learning model as an independent variable on the dependent variable in this study, namely creativity and mathematics achievement, the parametric analysis will be used, namely the Independent Samples $t$-Test. If the data is not normally distributed, a non-parametric test will be used in the form of the Mann-Whitney U Test. Then to find out the increase in the value of the pre-test and post-test of student achievement, Parametric Analysis Paired Samples $t$-Test was used if the data were normally distributed, while the Wilcoxon Signed Rank Test was used if the data was not normally distributed. The results were considered significant when $p<0.05$.

\section{RESULTS}

This study applies the Treffinger's learning model to increasing creativity and mathematics achievement of gifted students on trigonometry material on the topic of the rules of sine and cosine. This study begins by selecting gifted students according to inclusion and exclusion criteria, then randomization is carried out to determine students who enter into two classes, namely the experimental class which will be given the Treffinger's learning model and the control class which will be given the expository learning model. The learning process for trigonometry on the topic of the sine and cosine rules is carried out online using the Google Meet platform, Google Classroom, and WhatsApp groups.

The learning process is carried out for 1 month consisting of 4 meetings for each class. The first meeting carried out pre-test activities on March 12, 2021, then continued with two meetings discussing trigonometry material on the topic of the rules of sine and cosine using the Treffinger's learning model for the experimental class and the expository learning model for the control class. The fourth meeting carried out post-test activities, namely on March 30, 2021. The data obtained were tabulated, then analyzed according to the type of data.

The second meeting which discussed the sine rule in the experimental class using the Treffinger's learning model was held on March 16, 2021, while the control class was held on March 18, 2021, using the expository learning model. Then the third meeting which discussed the cosine rule in the experimental class using the Treffinger's learning model was held on March 23, 2021, while the 


\section{Jurnal Riset Pendidikan Matematika, 8 (2), 2021 - 132 \\ Kana Hidayati, Ni Kadek Swari Nandini, Mazlini Adnan}

control class was held on March 25, 2021, using the expository learning model. Learning activities in the experimental class invite students to form small groups so that discussing the student worksheet can be done with group discussions. In the control class, the learning that is carried out is centered on the teacher and students working on the student worksheets individually. Based on observations made during the learning process, students in the experimental class who were given the Treffinger's learning model tend to be more active in asking questions, discussing between friends, and being active in answering questions posed by the teacher while students in the control class tend to be silent when given questions. by the teacher and is not active in asking questions during learning. In addition, from observations made by the teacher, it can be seen that students in the experimental class found it easier to understand trigonometry material on the topic of the rules of sine and cosine compared to students in the control class.

\section{The effect of treffinger's learning model on gifted student creativity}

Based on Table 1, it is found that the average age of the experimental class students is $15.5 \pm 0.583$ years, while the average age of the control class students is $15.58 \pm 0.507$ years. In terms of gender, it was found that in the experimental class there were 11 male students and 15 female students. While in the control class, there were 6 male students and 13 female students.

Table 1. Basic characteristics of subjects in the experiment class and control class

\begin{tabular}{lcc}
\hline \multirow{2}{*}{ Variables } & \multicolumn{2}{c}{ Class } \\
\cline { 2 - 3 } & Experiment & Control \\
\hline Age $(\operatorname{mean} \pm S D)$ & $15.5 \pm 0.583$ & $15.58 \pm 0.507$ \\
Gender $n(\%)$ & & \\
$\quad$ Male & $11(42.3 \%)$ & $6(31.6 \%)$ \\
$\quad$ Female & $15(57.7 \%)$ & $13(68.4 \%)$ \\
\hline
\end{tabular}

\section{Experiment class creativity and control class}

Based on Table 2, the average creativity score of the experimental class students is 88.04 , while the average creativity score of the control class students is 78.58 .

Table 2. The average student creativity score in experiment class and control class

\begin{tabular}{lccccc}
\hline Class & $n$ & Min & Max & Mean & Standard Deviation \\
\hline Experiment & 26 & 72 & 105 & 88.04 & 8.19 \\
Control & 19 & 50 & 108 & 78.58 & 12.795 \\
\hline
\end{tabular}

Specifically, based on the aspect of student creativity, it can be divided into fluency, flexibility, originality, and elaboration. The category of student scores is divided into 5 categories, namely very low, low, medium, high, and very high. The following is a description of the results of students' creativity based on the four aspects of creativity.

\section{Fluency} in Table 3 .

The creativity of the experimental class and control class students on the fluency aspect is shown

Table 3. Student creativity in experiment class and control class on fluency

\begin{tabular}{clcc}
\hline Score & Category & Experiment $n(\%)$ & Control $n(\%)$ \\
\hline $8-12$ & Very low & $0(0.0 \%)$ & $2(10.5 \%)$ \\
$13-17$ & Low & $1(3.8 \%)$ & $4(21.1 \%)$ \\
$18-22$ & Medium & $7(26.9 \%)$ & $8(42.1 \%)$ \\
$23-27$ & High & $15(57.7 \%)$ & $5(26.3 \%)$ \\
$28-32$ & Very high & $3(11.5 \%)$ & $0(0.0 \%)$ \\
\hline
\end{tabular}

Table 3 shows that in the experimental class there are no students with very low fluency, $1(3.8 \%)$ students with low fluency, there are 7 (26.9\%) students with moderate fluency, $15(57.7 \%)$ students with high fluency, and $3(11.5 \%)$ students with very high fluency. While in the control class, there were 2 
(10.5\%) students with very low fluency, 4 (21.1\%) students with low fluency, 8 (42.1\%) students with moderate fluency, $5(26.3 \%$ ) students with high fluency, and there are no students with very high fluency.

\section{Flexibility}

The creativity of the experimental class and control class students on the aspect of flexibility is shown in Table 4.

Table 4. Student creativity in experiment class and control class in flexibility aspects

\begin{tabular}{clcc}
\hline Score & Category & Experiment $n(\%)$ & Control $n(\%)$ \\
\hline $8-12$ & Very low & $0(0.0 \%)$ & $0(0.0 \%)$ \\
$13-17$ & Low & $0(0.0 \%)$ & $0(0.0 \%)$ \\
$18-22$ & Medium & $12(46.2 \%)$ & $9(47.4 \%)$ \\
$23-27$ & High & $12(46.2 \%)$ & $10(52.6 \%)$ \\
$28-32$ & Very high & $2(7.7 \%)$ & $0(0.0 \%)$ \\
\hline
\end{tabular}

Table 4 indicates that in the experimental class there are no students with very low flexibility, there are no students with low flexibility, there are $12(46.2 \%)$ students with moderate flexibility, $12(46.2 \%)$ students with high flexibility, and $2(7.7 \%)$ students with very high flexibility. While in the control class, there were no students with very low flexibility, there were no students with low flexibility, there were $9(47.4 \%)$ students with moderate flexibility, $10(52.6 \%)$ students with high flexibility, and there were no students with very high flexibility.

\section{Originality}

The creativity of the experimental class and control class students in the aspect of originality is shown in Table 5.

Table 5. Creativity of experiment class and control class students on the aspect of originality

\begin{tabular}{clcc}
\hline Score & Category & Experiment $n(\%)$ & Control $n(\%)$ \\
\hline $8-12$ & Very low & $1(3.8 \%)$ & $0(0.0 \%)$ \\
$13-17$ & Low & $8(30.8 \%)$ & $11(57.9 \%)$ \\
$18-22$ & Medium & $10(38.5 \%)$ & $4(21.1 \%)$ \\
$23-27$ & High & $7(26.9 \%)$ & $3(15.8 \%)$ \\
$28-32$ & Very high & $0(0.0 \%)$ & $1(5.3 \%)$ \\
\hline
\end{tabular}

Table 5 shows that in the experimental class there are $1(3.8 \%)$ students with very low originality, there are $8(30.8 \%)$ students with low originality, there are $10(38.5 \%)$ students with moderate originality, there are $7(26.9 \%)$ students with high originality, and there are no students with very high originality. While in the control class, there were no students with very low originality, there were $11(57.9 \%)$ students with low originality, there were $4(21.1 \%)$ students with moderate originality, there were 3 $(15.8 \%)$ students with high originality, and there are $1(5.3 \%)$ students with very high originality.

\section{Elaboration}

The creativity of the experimental class and control class students in the elaboration aspect is shown in Table 6.

Table 6. Student creativity in experiment class and control class on elaboration aspect

\begin{tabular}{clcc}
\hline Score & Category & Experiment $n(\%)$ & Control $n(\%)$ \\
\hline $8-12$ & Very low & $0(0.0 \%)$ & $1(5.3 \%)$ \\
$13-17$ & Low & $2(7.7 \%)$ & $9(47.4 \%)$ \\
$18-22$ & Medium & $15(57.7 \%)$ & $3(15.8 \%)$ \\
$23-27$ & High & $8(30.8 \%)$ & $6(31.6 \%)$ \\
$28-32$ & Very high & $1(3.8 \%)$ & $0(0.0 \%)$ \\
\hline
\end{tabular}


Based on Table 6 , in the experimental class there are no students with very low elaboration, there are 2 (7.7\%) students with low elaboration, there are $15(57.7 \%)$ students with moderate elaboration, there are $8(30.8) \%$ ) students with high elaboration, and $1(3.8 \%)$ students with very high elaboration. While in the control class, there were $1(5.3 \%)$ students with very low elaboration, there were $9(47.4 \%)$ students with low elaboration, there were $3(15.8 \%)$ students with moderate elaboration, there were 6 $(31,6 \%)$ students with high elaboration, and there are no students with very high elaboration.

\section{Data normality test (Kolmogorov-Smirnov)} 0.05 .

Based on Table 7, the creativity score variable is normally distributed because the $p$ value >

Table 7. Normality test of creativity score data

\begin{tabular}{lc}
\hline Variabel & Nilai $p$ \\
\hline Creativity & 0.200 \\
\hline
\end{tabular}

\section{Test average creativity score experiment class and control class}

From the calculation results of the Independent Samples $t$-Test using SPSS statistics, it was found that the average difference I $\mathrm{n}$ creativity scores was 9.46 points between the experimental class and the control class, which was significant, marked by a $p$-value $=0.004$. Because the value of $p=$ 0.004 which is $p<0.05$ then $\mathrm{H}_{0}$ is rejected so that there is a significant difference between the creativity scores of the experimental class students and the control class students as shown in Table 8.

Table 8. Analysis of the average creativity score of the experiment class and the control class

\begin{tabular}{lccccccc}
\hline \multirow{2}{*}{ Variable } & \multicolumn{2}{c}{ Class } & Mean & $p-$ & \multicolumn{2}{c}{ CI95\% } \\
\cline { 2 - 3 } \cline { 7 - 8 } & Experiment & Control & Diff & Value & Lower & Upper \\
\hline Creativity Score & $88.04 \pm 8.190$ & $78.58 \pm 12.795$ & 9.460 & 0.004 & 3.148 & 15.771 \\
\hline
\end{tabular}

\section{The effect of Treffinger's learning model on mathematics achievement}

The average pre-test and post-test scores of the experimental class and control class students are shown in Table 9.

Table 9. Mathematics achievement of gifted student

\begin{tabular}{lcc}
\hline \multirow{2}{*}{ Variables } & \multicolumn{2}{c}{ Class } \\
\cline { 2 - 3 } & Experiment & Control \\
\hline Pre-test score (mean \pm SD) & $24.90 \pm 10.337$ & $16.50 \pm 10.430$ \\
Post-test score (mean \pm SD) & $83.27 \pm 11.655$ & $27.84 \pm 16.078$ \\
\hline
\end{tabular}

Based on Table 9, the average pre-test score of the experimental class students is $24.90 \pm 10.337$, while the average score of The pre-test of the control class students was $16.50 \pm 10.430$. The average post-test score of the experimental class students was $83.27 \pm 11,655$, while the average post-test score of the control class students was $27.84 \pm 16,078$.

\section{Data normality test (Kolmogorov-Smirnov)}

Table 10 represents that the pre-test variables are normally distributed because the $p$-value $>0.05$.

Table 10. Normality test of pre-test and post-test score data

\begin{tabular}{lc}
\hline Variable & Nilai $p$ \\
\hline Learning Achievement & \\
Pre-test & 0.068 \\
Post-test & 0.002 \\
\hline
\end{tabular}


Jurnal Riset Pendidikan Matematika, 8 (2), 2021 - 135

Kana Hidayati, Ni Kadek Swari Nandini, Mazlini Adnan

The average pre-test score, post-test score, and gain score experiment class and control class

Table 11 presents the data of the pre-test, post-test, and gain score for the experimental class and control class.

Table 11. Analysis of the average pre-test score, post-test score, and gain score for the experimental class and control class

\begin{tabular}{lcccccc}
\hline \multirow{2}{*}{ Variable } & \multicolumn{2}{c}{ Class } & Mean & $p$ - & \multicolumn{2}{c}{ CI95\% } \\
\cline { 2 - 3 } \cline { 7 - 7 } & Experiment & Control & Diff & Value & Lower & Upper \\
\hline $\begin{array}{l}\text { Pre-test score } \\
\text { (mean } \pm \text { SD) }\end{array}$ & $24.90 \pm 10.337$ & $16.50 \pm 10.430$ & 8.404 & 0.010 & 2.088 & 14.719 \\
$\begin{array}{l}\text { Post-test score } \\
(\text { mean } \pm \text { SD) }\end{array}$ & $83.27 \pm 11.655$ & $27.84 \pm 16.078$ & 55.427 & $<0.001$ & 47.099 & 63.755 \\
Gain score (mean \pm SD) & $58.365 \pm 12.878$ & & & & & \\
\hline
\end{tabular}

From the results of the calculation of the Independent Samples $t$-Test using SPSS statistics, it was found that the difference in the average pre-test score of 8.404 points between the experimental class and the control class was significant, marked by a $p$-value $=0.010$. Because the value of $p=0.010$ is $p<0.05$, then $\mathrm{H}_{0}$ is rejected so that there is a significant difference between the pre-test scores of the experimental class students and the control class students. From the calculation results of the Mann Whitney U Test using SPSS statistics, it was found that the difference in the average post-test score of 55,427 points between the experimental class and the control class was significant, marked by a $p$-value $<0.001$. Because the value of $p<0.001$ is $p<0.05$, then $\mathrm{H}_{0}$ is rejected so that there is a significant difference between the post-test scores of the experimental class students and the control class students. From the results of the calculation of the Paired samples $t$-Test using SPSS statistics, it was found that the difference in the average gain score between the post-test and pre-test scores of students in the experimental class was 58.365 points marked with a $p$-value $<0.001$. Because the value of $p<0.001$ is $p<0.05$, then $\mathrm{H}_{0}$ is rejected so that the gain score between the post-test and pre-test scores of students in the experimental class is significantly different.

\section{DISCUSSION}

Creativity in mathematics is a very broad terminology. Creativity in mathematics is defined as the ability to produce original work and be able to broaden students' horizons, be able to produce new problem solutions (novels) and be able to formulate new questions that allow solving existing problems from a different point of view. Therefore, this study assesses the creativity aspects of gifted students from 4 different domains, namely fluency, flexibility, originality, and elaboration (Sharma, 2014: 27). This study found that the average creativity score of the experimental class (88.04) was higher than the average creativity score of the control class (78.58), which was significantly significant with $p=0.004$. This shows that students in the experimental class have a higher overall level of creativity than students in the control class. The results of this study are slightly different from previous studies, such as the research of Wiladah (2017: 66) which found that the creativity scores of students in the experimental class given the Treffinger's learning model and the control class given the expository learning model were relatively the same, namely in the medium category (Wiladah, 2017: 67). The results of this study are also in line with Rochani's research (2016: 273) which found problem-based learning concepts can improve critical thinking skills with a $p$-value of $<0.05$.

This study found that the creativity of students, especially in the fluency aspect, students in the experimental class, the majority had high fluency as many as $15(57.7 \%)$ students. Meanwhile, in the control class, the majority of students had moderate fluency, as many as $8(42.1 \%)$ students. This shows that in this study, creativity from the fluency aspect was better in the experimental class. The results of this study are slightly different from the findings of Wiladah's research which found that the fluency aspect of creativity in experimental and control class students was moderate (Wiladah, 2017: 69). This study found that students in the experimental class, the majority had moderate and high flexibility, respectively $12(46.2 \%)$ students. While in the control class, the majority of students have a high flexibility aspect, as many as $10(52.6 \%)$ students. This shows that in this study, creativity from the 


\title{
Jurnal Riset Pendidikan Matematika, 8 (2), 2021 - 136
}

\author{
Kana Hidayati, Ni Kadek Swari Nandini, Mazlini Adnan
}

aspect of flexibility is relatively the same in both classes. The results of this study are slightly different from the findings of Wiladah's research which found that the creativity aspect of flexibility in experimental and control class students was moderate (Wiladah, 2017: 70).

In this study, it was found that the students in the experimental class, the majority had moderate originality, as many as $10(38.5 \%)$ students. While in the control class, the majority of students had low originality, as many as $11(57.9 \%)$ students. This shows that in this study, creativity from the aspect of originality was better in the experimental class. The results of this study are slightly different from the findings of Wiladah's research which found that the creativity aspect of originality in experimental and control class students was moderate (Wiladah, 2017: 71). In this study, it was found that the students in the experimental class, the majority had moderate elaboration, as many as $15(57.7 \%)$ students. While in the control class, the majority of students had low elaboration aspects, as many as $9(47.4 \%)$ students. This shows that in this study creativity from the elaboration aspect was higher in the experimental class. The results of this study are slightly different from the findings of Wiladah's research which found that the creativity aspect of elaboration in experimental and control class students was moderate (Wiladah, 2017: 72).

The Treffinger's learning model provides higher student creativity results than students with conventional learning models because this model facilitates students to practice divergent thinking and allows students to think more actively and share their solutions. This will also help expand students' cognitive abilities because each student will be more motivated to think creatively and be different from other students in solving problems (Lince, 2016: 210; Khuziakhmetov \& Gorev, 2017: 645). This study found that the average pre-test of the experimental class $(24.90 \pm 10.337)$ was higher than the mean of the pre-test of the control class $(16.50 \pm 10.430)$ which was significant with $\mathrm{p}=0.010$. This shows that students in the experimental class have a higher average pre-test compared to students in the control class. Furthermore, this study also found that the post-test average of the experimental class $(83.27 \pm 11.655)$ was higher than the post-test mean of the control class $(27.84 \pm 16.078)$ which was significantly significant with $p<0.001$. This shows that students in the experimental class have a higher post-test average than students in the control class. This result is following Isnaini's research which found that there was an increase in the average pre-test score to post-test of the creative thinking abilities of seventh-grade students of SMP 16 Banda Aceh by $15.667 \pm 18.971$. The study also found an increase in the average pre-test score to post-test of the problem-solving ability of $12,067 \pm 7,353$. This shows that students who are given learning using the Treffinger learning model show an increase both in terms of learning achievement abilities and the level of creativity assessed from the aspect of creative thinking and problem solving (Isnaini et al., 2016: 42).

This study found that the increase in the average pre-test score to post-test in the experimental class was $58.365 \pm 12.878$ which was significantly significant with $p<0.001$. This shows that Treffinger's learning model can increasing mathematics achievement in trigonometry material on the topic of the rules of sine and cosine. The results of this study are in line with the research of Sari and Putra who assessed the level of critical and creative thinking in Kanjuruhan University students, Malang. The study found that the average gain score in the experimental class that received learning using the Treffinger learning model experienced an increase of 30.9 in critical thinking skills and 30.3 in creative thinking skills which were significantly marked by a $p$-value $<0.05$ ( Sari \& Putra, 2015: 34). The results of this study are also in line with Rochani's research (2016: 273) which found problem-based learning concepts can improve cognitive learning outcomes with a $p$-value of $<0.05$. Furthermore, the results of this study are also in line with the research of Lintuman and Wijaya (2020: 13) which obtained significant results on the learning achievement variable.

From these results, it can be seen that Treffinger's learning model not only increases creativity but also student achievement. This is possible because Treffinger's learning model can stimulate 3 domains of mathematical ability, namely knowing, applying, and solving novel problems. Knowing is facilitated by the opportunity for students to know the basic principles, procedures, and concepts of solving mathematical problems. Then at the applying stage, students are allowed to apply previously known conceptual knowledge and understanding to solve common problems. Then at the novel problemsolving stage, students are required to transfer knowledge and abilities into new problem situations that require reasoning and planning skills. This will help students to solve problems correctly and completely (Männamaa et al., 2012; Sheromova et al., 2020). 
In this study, sampling in the form of gifted students was only based on large IQ scores with a range of 125 to 140 only. So that the definition used does not include the definition of gifted or special intelligent gifted children who are categorized as children with high IQ abilities above average, have high commitment to tasks, and high creativity. This causes the number of gifted students in this study to have a larger proportion, which is more than $40 \%$ of students compared to the proportion of gifted students mentioned in some literature, which is only $2 \%$ to $5 \%$. In addition, this study also carried out the process of measuring the creativity level of experimental class students who received the Treffinger's learning model and control class students who received the expository learning model. However, from these measurements, the researchers in this study did not measure the speed of students when the process of measuring creativity. In completing this research, teaching and learning activities could not be carried out face-to-face as they should be due to pandemic conditions. So that researchers overcome this limitation by conducting online learning activities through the google meet platform, google classroom, and WhatsApp groups. However, in general, this limitation does not reduce the implementation process, meaning, and usefulness of the results of this study.

\section{CONCLUSION}

From this study, it can be concluded that the Treffinger's learning model is effective in increasing creativity of gifted students in trigonometry material on the topic of the sine and cosine rules in terms of fluency, flexibility, originality, and elaboration aspects which are marked by the significantly higher average score of creativity of experimental class students at 9.46 points compared to the average creativity of the control class students. In addition, the Treffinger's learning model is effective in increasing mathematics achievement of gifted students in trigonometry material on the topic of the sine and cosine rules which can be seen from the difference in the gain score of the post-test and pre-test values in the experimental class which is significantly significant from the results of the Paired Samples $\mathrm{T}$-Test with a p-value of $<0.001$. In the future, further research is needed on the Treffinger's learning model in gifted student populations in other areas to generalize the findings of this study more broadly. In addition, further research is needed on Treffinger's learning model in face-to-face learning settings so that it can be used as a reference in the learning process of trigonometry material on the topic of sine and cosine rules.

\section{REFERENCES}

Akbar, P., Syaodih, E., \& Lisnawati, C. (2015). Efektivitas model pembelajaran treffinger untuk meningkatkan kemampuan berpikir kreatif siswa [The effectiveness of the treffinger learning model to improve students' creative thinking skills]. JP2EA, 1(1), 33-46. http://jurnal.fkip.unla.ac.id/index.php/jp2ea/article/view/111

Darminto, B. P. (2013). Meningkatkan kemampuan pemecahan masalah matematis mahasiswa melalui pembelajaran model treffinger [Improving students' mathematical problem solving skills through learning the treffinger model]. Jurnal Pendidikan Matematika dan Sains, 1(2), 101-107. https://journal.uny.ac.id/index.php/jpms/article/view/2476

Desiningrum, D. R. (2016). Psikologi anak berkebutuhan khusus [Psychology of children with special needs]. Psikosain.

Idrus, M. (2013). Layanan pendidikan bagi anak gifted [Educational services for gifted children]. PSIKOPEDAGOGIA Jurnal Bimbingan dan Konseling, 2(2), 116-131. http://dx.doi.org/10.12928/psikopedagogia.v2i2.2579

Isnaini, I., Duskri, M., \& Munzir, S. (2016). Upaya meningkatkan kreativitas dan kemampuan pemecahan masalah matematika siswa sekolah menengah pertama melalui model pembelajaran treffinger [Efforts to improve creativity and mathematical problem solving abilities of junior high school students through the treffinger learning model]. Jurnal Didaktik Matematika, 3(1), 15-25. http://jurnal.unsyiah.ac.id/DM/article/view/4301

Khumaidi, W., Wibowo, M. A., \& Asriyah, M. (2019). Mendidik anak supernormal dalam perspektif pendidikan Islam [Educating supernormal children in the perspective of Islamic education]. An Naba': Jurnal Pemikiran dan Penelitian Pendidikan Islam, 2(1), 21-34. https://ejournal.iaitribakti.ac.id/index.php/tribakti/article/view/482 
Khuziakhmetov, A. N., \& Gorev, P. M. (2017). Introducing learning creative mathematical activity for students in extra mathematics teaching. Bolema - Mathematics Education Bulletin, 31(58), 642657. https://doi.org/10.1590/1980-4415v31n58a06

Lince, R. (2016). Creative thinking ability to increase student mathematical of junior high school by applying models numbered heads together. Journal of Education and Practice, 7(6), 206-212. https://files.eric.ed.gov/fulltext/EJ1092494.pdf

Lintuman, A., \& Wijaya, A. (2020). Keefektifan model pembelajaran berbasis inkuiri ditinjau dari prestasi belajar dan kepercayaan diri dalam belajar matematika siswa SMP [The effectiveness of the inquiry-based learning model in terms of learning achievement and self-confidence in learning mathematics for junior high school students]. Jurnal Riset Pendidikan Matematika, 7(1), 13-23. https://journal.uny.ac.id/index.php/jrpm/article/view/17878

Maharani, R. K. (2018). Pengaruh model pembelajaran treffinger terhadap kemampuan berpikir kreatif pelajaran matematika materi bangun ruang [The effect of the treffinger learning model on the ability to think creatively in mathematics lessons on geometrical material]. JPGSD, 6(4), 506515. https://ejournal.unesa.ac.id/index.php/jurnal-penelitian-pgsd/article/view/23615

Männamaa, M., Kikas, E., Peets, K., \& Palu, A. (2012). Cognitive correlates of math skills in thirdgrade students. Educational Psychology, 32(1), 21-44. https://doi.org/10.1080/01443410.2011.621713

Nisa, T. F. (2011). Pembelajaran matematika dengan setting model treffinger untuk mengembangkan kreativitas siswa [Learning mathematics with the treffinger model setting to develop students' creativity]. PEDAGOGIA, 1(1), 35-48. https://doi.org/10.21070/pedagogia.v1i1.31

Pomalato, S. (2006). Mengembangkan kreativitas matematik siswa dalam pembelajaran matematika melalui pendekatan model treffinger [Develop students' mathematical creativity in learning mathematics through the treffinger model approach]. Mimbar Pendidikan, XXV(1), 22-26. http://file.upi.edu/direktori/jurnal/jurnal_mimbar_pendidikan/mimbar_no_1_2006/mengembang kan_kreativitas_matematik_siswa_dalam_pembelajaran_matematika_melalui_pendekatan_mod el_treffinger.pdf

Rochani, S. (2016). Keefektifan pembelajaran matematika berbasis masalah dan penemuan terbimbing ditinjau dari hasil belajar kognitif kemampuan berpikir kreatif [The effectiveness of problembased mathematics learning and guided discovery in terms of cognitive learning outcomes of creative thinking skills]. Jurnal Riset Pendidikan Matematika, 3(2), 273. http://dx.doi.org/10.21831/jrpm.v3i2.5722

Sari, Y. I., \& Putra, D. F. (2015). Pengaruh model pembelajaran treffinger terhadap kemampuan berpikir kritis dan kreatif mahasiswa Universitas Kanjuruhan Malang [The effect of the Treffinger learning model on the critical and creative thinking skills of Kanjuruhan University students, Malang]. Jurnal Pendidikan Geografi, 20(2), 30-38. http://journal.um.ac.id/index.php/pendidikan-geografi/article/view/5065

Sharma, Y. (2014). The effects of strategy and mathematics anxiety on mathematical creativity of school students. International Electronic Journal of Mathematics Education, 9(1-2), 25-37. https://doi.org/10.29333/iejme/279

Sheromova, T. S., Khuziakhmetov, A. N., Kazinets, V. A., Sizova, Z. M., Buslaev, S. I., \& Borodianskaia, E. A. (2020). Learning styles and development of cognitive skills in mathematics learning. Eurasia Journal of Mathematics, Science and Technology Education, 16(11). https://doi.org/10.29333/ejmste/8538

Sunardi. (2008). Karakteristik dan kebutuhan anak berbakat dan implikasi dalam layanan bimbingan dan konseling karir [Characteristics and needs of gifted children and implications in career guidance and counseling services]. http://file.upi.edu/direktori/fip/jur._pend._luar_biasa/196002011987031-sunardi/karya_tlsmateri_ajar_pdf/konseling_karir_anak_berbakat.pdf 
Tiel, V., Maria, J., \& Widyorini, E. (2014). Deteksi dan penanganan anak cerdas istimewa (anak gifted) melalui pola alamiah tumbuh kembangnya [Detection and handling of special intelligent children (gifted children) through natural patterns of growth and development]. Prenadamedia Group.

Wandansari, Y. (2011). Faktor protektif pada penyesuaian sosial anak berbakat [Protective factors on the social adjustment of gifted children]. Insan, 13(02), 85-95. http://journal.unair.ac.id/downloadfull/INSAN4301-29b670b358fullabstract.pdf

Wiladah, R. K. (2017). Perbedaan penggunaan model treffinger dan model pembelajaran langsung terhadap kreativitas dan hasil belajar matematika siswa di kelas XI SMA Negeri 14 Makassar [Differences in the use of the treffinger model and direct learning model on creativity and mathematics learning outcomes of students in class XI SMA Negeri 14 Makassar]. Universitas Negeri Makassar, 1-99. http://eprints.unm.ac.id/id/eprint/6122

Wulandari, D. A., \& Afifah, D. S. N. (2019). Kreativitas siswa dalam menyelesaikan soal matematika berdasarkan tingkat kemampuan matematika [Student creativity in solving math problems based on the level of mathematical ability]. Prima: Jurnal Pendidikan Matematika, 3(1), 57-66. http://dx.doi.org/10.31000/prima.v3i1.770 